\title{
Assessment of Selected Aspects of the Quality of Life of Children with Type 1 Diabetes Mellitus in Poland
}

\author{
Justyna Grudziąż-Sękowska ${ }^{1, * \mathbb{D}}$, Monika Zamarlik ${ }^{2}$ and Kuba Sękowski ${ }^{3}$ \\ 1 Centre of Postgraduate Medical Education, School of Public Health, 01-813 Warsaw, Poland \\ 2 Faculty of Health Sciences, Institute of Public Health, Jagiellonian University, 31-007 Kraków, Poland; \\ monika.zamarlik@doctoral.uj.edu.pl \\ 3 Doctoral School, Law College, Kozminski University, 03-301 Warsaw, Poland; kuba.sekowski@gmail.com \\ * Correspondence: jgrudziaz@cmkp.edu.pl; Tel.: +48-225-601-150
}

Citation: Grudziąż-Sękowska, J.;

Zamarlik, M.; Sękowski, K.

Assessment of Selected Aspects of the Quality of Life of Children with Type 1 Diabetes Mellitus in Poland. Int. J. Environ. Res. Public Health 2021, 18 , 2107. https://doi.org/10.3390/ ijerph18042107

Academic Editor: Cindy M. Padilla

Received: 1 January 2021

Accepted: 16 February 2021

Published: 22 February 2021

Publisher's Note: MDPI stays neutral with regard to jurisdictional claims in published maps and institutional affiliations.

Copyright: (c) 2021 by the authors. Licensee MDPI, Basel, Switzerland. This article is an open access article distributed under the terms and conditions of the Creative Commons Attribution (CC BY) license (https:// creativecommons.org/licenses/by/ $4.0 /)$.

\begin{abstract}
Type 1 diabetes mellitus (T1D) is, next to obesity and asthma, the most common chronic disease in children in Poland. T1D is not only a medical challenge, but it also affects all areas of a sick child's life and family functionality. New forms of therapy facilitate the daily management of the disease, but their availability is limited and partly dependent on socioeconomic status. This study aimed to assess the incidence and interrelationships between the child's health condition and the applied therapy model, and selected aspects of the child's family functionality and access to health and care services. The survey involved 206 child and youth caregivers with T1D who are members of Facebook support groups. The analysis of the obtained results revealed the existence of links between family income level and the type of insulin therapy applied. Children from families with a better financial situation (subjective and objective) were more likely to have additional medical consultations and make more frequent control visits. In families with a higher level of income, the T1D-induced restriction of child activity was less frequent. Living outside of urban centers was associated with a reduced availability of care or educational facilities adapted to take care of a child with T1D. No statistically significant correlations were observed between demographic and economic factors and the child's health status expressed by the occurrence of complications. The incidence of the latter, however, affected the child's family situation.
\end{abstract}

Keywords: children; diabetes mellitus; type 1; health status disparities; social inequalities

\section{Introduction}

Type 1 diabetes (T1D) is an immune-mediated disease. It is a disorder characterized by the progressive destruction of beta cells in the pancreas, leading to the cessation of insulin secretion and subsequent hyperglycemia [1,2]. The exact cause of the destruction of pancreatic $\beta$ cells is not fully known, but some factors are indicated that initiate their destruction by the immune system. These include not only genetic factors [3,4], but also environmental factors (including rubella viruses, mumps viruses, cytomegaloviruses, and the consumption of cow's milk protein) [5]. T1D is a chronic disease that requires a constant external insulin supply.

Despite technological advances in pharmacotherapy, insulin delivery devices, and glycemia measurement, T1D treatment presents patients and their families with challenges that affect most aspects of their daily lives [6]. Maintaining adequate metabolic control to minimize the risk of diabetes-related complications while maintaining a flexible lifestyle and quality of life is a particular challenge for the youngest patients-children and adolescents.

The last few decades have seen a significant increase in the incidence of T1D worldwide. This corresponds to an increase of over 120,000 new T1D cases in children and adolescents up to 19 years of age per year. The largest increase is in the population of the youngest children ( $<5$ years), for whom living with the disease will be the greatest 
burden. In Europe, there has been an overall annual increase in the incidence of T1D of $3.9 \%$ recorded, and the incidence rate has been projected to double for children $<5$ years old between 2005 and 2020. [7]

The increasing prevalence of T1D in developed countries is worrying because T1D negatively affects quality and life expectancy, mainly due to the diseases and deaths resulting from its chronic complications [8,9]. Children from low-income families with an unfavorable socioeconomic status are more likely to suffer from the adverse course of the disease, worse glycemic control, and less access to new, expensive medical technologies, and, thus, incur a higher risk of health complications [10].

In 2018 in Poland, nearly 22,000 people under 18 years of age were suffering from T1D. This constituted $3.17 \%$ of the underage population (a 2.5\% increase compared to 2013) [11]. In some regions of Poland, the T1D maturity rate in the $0-4$ age group increased by more than 2.5 times. [12]. In Poland, most of the latest treatment technologies are available to facilitate the daily functioning of T1D patients. However, not all of them are reimbursed under the general health insurance system. In Poland, there is only one public payer (the National Health Fund). A significant proportion of medicinal products (including insulin and accessories for personal insulin pumps, as well as continuous glycemic monitoring (CGM) systems) require partial payment by the patient. There is no private (supplementary or complementary) health insurance covering pediatric diabetology

In 2018, 18,900 thousand patients benefited from treatment with a personal insulin pump (a 60\% increase compared to 2013) [11]. Since 2018, CGM technologies have been partially refunded for persons up to 26 years old. During the first year, 3100 patients gained access to CGM technology. The level of reimbursement by the public payer was $68.9 \%$ on average (16 million PLN, approximately 4 million EUR) [11]. The remaining costs of the CGM systems were borne directly by patients (via out of pocket payments).

Considering its level of economic development, Poland is not a country with gross economic inequalities. Their level of economic inequality is lower than that in other Central and Eastern European countries undergoing a similar process of economic transformation. At the same time, income disparities in Poland are high compared to richer EU countries [13]. In Poland, there are also significant deficiencies in terms of social infrastructure. The insufficient availability of institutional forms of childcare services (nurseries and kindergartens) and their inadequacy to care of children with chronic diseases (including T1D [14]) limit the ability of children and adolescents with T1D to lead a life appropriate for their healthy peers and constitute a significant burden for their families [15]. The need for personal care of a sick child is a significant burden for caregivers, often leading to a reduction in their professional activity and threatening to lower their socioeconomic status.

Therefore, it becomes important to assess the overall quality of life of children with T1D, taking into account the impact of the disease on their ability to function in society and their family situation, including their socioeconomic status [16-19].

Previous studies often used the diabetes-specific Diabetes Quality of Life for Youth (DQOLY) questionnaire [20]. That questionnaire provides information on the quality of life specific to teenagers with diabetes [21]. To assess the quality of life of a wider population of T1D children, the Pediatric Quality of Life Inventory (PedsQL) 3.0 Diabetes Module was developed [22-24]. It allows for the comparison of the quality of life of children with T1D with that of a population of healthy children. These tools have enabled a reliable assessment of the quality of life of children with T1D [22]. The fundamental part of the evaluation remains valid with regard to Poland [25]. The results obtained with the use of these quality of life assessment tools are often correlated with data on applied therapy and its outcomes, e.g., metabolic control, and number of hypo- and hyperglycemic episodes [26,27]. However, there are no studies on the access of children and young people with T1D to health benefits and care services, which is a problem in Poland [15].

The aim of the study was to assess the incidence and interrelationships between the child's health condition and the applied therapy model, and selected aspects of the child's family functionality and access to health and care services. For this purpose, a specially 
designed questionnaire was used which, in addition to the information used in DQOLY and PedsQL about the most recent hemoglobin A1c (HbA1c) levels, included questions about the impact of the disease on selected aspects of the child's family functionality and access to health benefits and care services.

Due to the important, constantly growing role of the Internet-as a place of searching for information, contact, and support for patients with T1D [28,29]-the survey was conducted among social media users associated in groups with families of children and adolescents with T1D.

The research program under which the study was conducted received a positive assessment from the IRB of the Centre of Postgraduate Medical Education (no. 501-4-4428-18). All the procedures performed in the study involving human participants were in accordance with the ethical standards of the institutional and national research committee, as well as with the 1964 Helsinki Declaration and its later amendments or comparable ethical standards.

\section{Materials and Methods}

\subsection{Data Collection}

The research material consisted of the data collected through questionnaires addressed to the caregivers of children diagnosed with type 1 Diabetes. The survey was conducted in the autumn of 2019 through Facebook groups of T1D caregivers: "Let's help each other" type 1 diabetes mellitus and "Let's get the colors of life back" type 1 diabetes mellitus. These groups have a total of more than 17,000 members who have one or more T1D children in their care (which functioned as an inclusion criterion). The group members were invited to fill in the questionnaire in electronic form (CAWI). Before completing the questionnaire, the participants were informed about the scope and purpose of the study, as well as about the voluntary and anonymous nature of the answers provided. The study (questionnaire) was not connected with any intervention (diagnostic or therapeutic), nor did it constitute a part of such an intervention. Therefore, according to Polish regulations on the provision of health services, obtaining qualified informed consent was not required.

To avoid multiple completions of the survey by the same respondents who could belong to both of the indicated groups, duplicate records were removed from the obtained answers. The criteria for qualifying the record as recurring were the same answers to questions about the child's name and date of birth. Records for people over 18 years have also been deleted (as an exclusion criteria). Any information on persons subject to exclusion was not subsequently processed and was removed from the dataset. In accordance with the applicable regulations on personal data protection, the survey did not include information that could identify the respondent (caregiver) or the child they cared for.

In total, 233 complete questionnaires were completed. After eliminating the questionnaires concerning patients over 18 years of age, 212 questionnaires were obtained. After eliminating the duplicates, 206 questionnaires were received (Figure 1).

\subsection{Variables}

The survey questions were divided into four modules (groups of variables), concerning, respectively:

1. Demographic data of the child and parent/caregiver-module I;

2. Information on the child's health and therapy-module II;

3. Information about the impact of the disease on family and child life-module III;

4. Information on the provision of care for the child by other persons or institutionsmodule IV. 


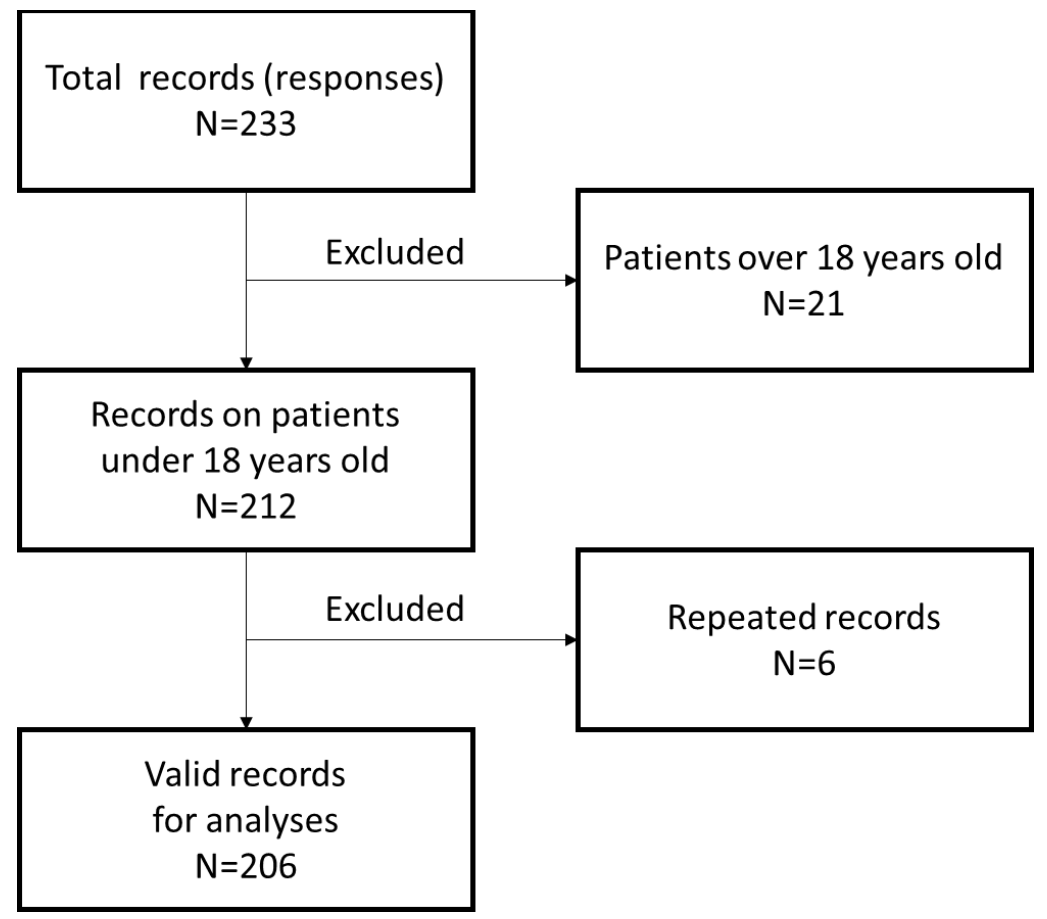

Figure 1. Flow chart of data collection.

\subsubsection{Demographic Data-Module I}

The demographic dataset included: the child's age (in full years); the child's gender; the child's family situation (full family—a family with two adults raising a child/children; single-parent family — a family with one adult raising a child/children; other-in the case of raising a child outside the biological or adoptive family); primary caregiver-the person caring for the child in the context of the disease (mother or father-also, in the case of adopted children, relative, another person-caregiver); primary caregiver age (in full years); the child's place of residence (a village, a town with up to 20,000 inhabitants, a town with 20,000-100,000 inhabitants, a city with 100,000-500,000 inhabitants, a city with over 500,000 inhabitants); subjective assessment of the economic situation of the family (using a five-point Likert scale); and objective assessment of the family's economic situation (income per person in the household at intervals of PLN 500/EUR 110).

\subsubsection{Health Status-Module II}

Data on the child's health status included: the age of onset of T1D (in full years); the model of insulin therapy used (CSII or MDI); the type of doctor treating the child (diabetologist, GP, or other doctor); the frequency of visits to the attending physician (one, two, three, or four or more times a year); regularity of visits to the attending physician (regularly, irregularly at the will of the child's caregiver or irregularly due to the limited availability of visits); specialist consultations in the last 12 months (with an ophthalmologist, neurologist or other doctor); specialist consultations during the last 5 years or since the disease (with an ophthalmologist, neurologist or other physician); and T1D complications diagnosed in the child (none, ophthalmologist, nephrologist, or dermatologist).

\subsubsection{Impact on Child's and Family's Life-Module III}

The impact of the child's disease on the situation of this child and their family was assessed in relation to the following areas: changes in the professional activity of the caregivers and its reasons; changes in the family situation (it was possible to indicate more than one answer describing changes in the division of responsibilities, financial situation, and emotional relations in the family), concerns about the disease in the caregiver and/or child (it was possible to indicate more than one statement describing the feelings of the 
caregiver and the child) and the amount of expenses related to the child's therapy (the level of monthly private expenses at intervals of PLN 100/22EUR).

\subsubsection{Impact on Child's and Family's Life-Module III}

A child's illness can cause social exclusion, which first affects the child and then affects their family. The following variables were used to assess the occurrence of symptoms of social exclusion associated with developing T1D: the possibility of entrusting childcare to another person during the day, the possibility of entrusting such care during the night, the child's attendance at care/educational institutions (nursery, kindergarten, school), and the reasons for not attending such institutions.

\subsection{Statistical Analysis}

The collected data were subjected to statistical analysis. In order to determine the characteristics of the surveyed population, descriptive statistics tools were used, and the Pearson Chi-square test and Cramer's V coefficient were used to assess the relationship between individual variables. Statistical analysis was performed in the IBM SPSS Statistics version 26 program (IBM Corp., Armonk, NY, USA) with the statistical significance level $p<0.05$.

\section{Results}

\subsection{Participants Characteristics}

Information was collected on 206 T1D children (Table 1), 109 (52.9\%) of whom were girls and $97(47.1 \%)$ were boys. These groups did not differ in terms of the presence of the examined factors. The average age of the children was 7.91 years $(\mathrm{SD}=4.45)$. Most of the children $(>90 \%)$ lived in cities, more than half of whom lived in big cities and the largest cities. $66.5 \%$ of the respondents were brought up in complete families, and less than $2 \%$ (three cases) were brought up outside of their families.

Table 1. Demographic characteristics of participants $(\mathrm{N}=206)$.

\begin{tabular}{|c|c|c|c|c|c|}
\hline Characteristics & $\begin{array}{c}\text { Villages and } \\
\text { Towns } \\
\mathbf{N}=19\end{array}$ & $\begin{array}{c}\text { Small Cities } \\
(<20,000 \\
\text { Inhabitants }) \\
N=32\end{array}$ & $\begin{array}{c}\text { Medium Cities } \\
(20,000-100,000 \\
\text { Inhabitants) } \\
N=46\end{array}$ & $\begin{array}{c}\text { Big Cities } \\
(100,001-500,000 \\
\text { Inhabitants) } \\
\mathbf{N}=81\end{array}$ & $\begin{array}{c}\text { Largest Cities } \\
(>500,000 \\
\text { Inhabitants) } \\
N=28\end{array}$ \\
\hline Child's age (years) & $7.74(4.68)$ & $\begin{array}{c}9.22 \\
(4.46)\end{array}$ & $\begin{array}{c}8.00 \\
(4.37)\end{array}$ & $\begin{array}{c}7.33 \\
(4.48)\end{array}$ & $\begin{array}{c}8.07 \\
(3.96)\end{array}$ \\
\hline Caregiver's age (years) & $41.63(8.30)$ & $\begin{array}{l}43.31 \\
(9.69)\end{array}$ & $\begin{array}{c}41.65 \\
(10.08)\end{array}$ & $\begin{array}{l}40.07 \\
(9.90)\end{array}$ & $\begin{array}{l}38.71 \\
(8.44)\end{array}$ \\
\hline \multicolumn{6}{|c|}{ Child's family situation } \\
\hline Two-parent family (cases) & 14 & 24 & 33 & 50 & 16 \\
\hline One-parent family (cases) & 5 & 8 & 13 & 29 & 11 \\
\hline Other (cases) & - & - & - & 2 & 1 \\
\hline
\end{tabular}

Due to the size of the sample $(\mathrm{N}=206)$, the groups of respondents distinguished on the basis of some of the demographic characteristics (particularly place of residence and family situation combined with gender and age) were so small as to make it impossible to obtain statistically significant results showing their association with data from the other modules of the questionnaire. Statistically significant results were obtained only when the whole sample was analyzed. This was the case, for example, for the revealed associations between family type and the level of concern of the child and the caregiver.

\subsection{Correlations between Groups of Variables (Modules)}

A number of statistically significant correlations between pairs of variables from individual modules were identified. The strength of association of these variables-as measured by Cramer's V coefficient-was varied, and ranged from 0.808 (signaling a 
very strong relationship) to 0.140 (signaling a weak relationship). The greatest number of correlations was observed between the variables from module I (demographic data) and the variables from module III (the impact of the disease on the life of the child and family); 19 statistically significant correlations out of 49 (38\%) possible correlations between pairs of variables were found with these modules. There was an association between the variables from module III and the variables from module II (data on health and treatment); 15 statistically significant correlations out of $56(26.8 \%)$ possible associations were present. The variables from module IV (data on the possibility of providing care outside the child's family) were related to the variables from module I in 5 out of $21(23.8 \%)$ possible cases, and with the variables from module II in 4 out of $24(16.7 \%)$ possible cases. Numerous links were also observed between the variables characterizing the child's demographic situation (module I) and those describing their health and treatment (module II).

There were statistically significant relationships between 16 out of the $56(28.6 \%)$ pairs of variables from these modules. Correlations also occurred between the variables belonging to individual modules. These correlations were, respectively: 6 out of $21(28.6 \%)$ cases in module I, 26 out of $28(92.8 \%)$ cases in module II, 16 out of $21(76.2 \%)$ cases in module III, and 2 out of $3(66.6 \%)$ cases in module IV.

\subsubsection{Correlation between Demographic Factors and Health Status}

The average income per person in the family was the factor with the highest number and strength of correlation with the data illustrating the health condition and treatment of the child. The income level correlated most strongly with the type of insulin therapy applied. The average monthly income per family member of all families of children using MID (58 cases) was in the four lowest ranges ( $<$ PLN 2,000, approx. EUR 500). Among those using insulin pumps, this level of income was found in $48 \%$ of cases. Children from families with a better financial situation (subjective and objective) used additional medical consultations more often and made more frequent control visits. The child's place of residence influenced both the choice of insulin therapy method and the use of additional specialist consultations. No statistically significant correlation was observed between the child's demographic situation and the occurrence of complications or the main physician.

Detailed information on the number and strength of the observed connections is presented in Table 2.

Table 2. Correlation between demographic factors and health status.

\begin{tabular}{|c|c|c|c|c|c|c|c|}
\hline $\begin{array}{l}\text { Cramer's V } \\
(p \text {-Value }) 1\end{array}$ & $\begin{array}{l}\text { Child's } \\
\text { Age }\end{array}$ & $\begin{array}{c}\text { Caregiver's } \\
\text { Age }\end{array}$ & $\begin{array}{c}\text { Family } \\
\text { Type }\end{array}$ & $\begin{array}{c}\text { Main } \\
\text { Caregiver }\end{array}$ & $\begin{array}{c}\text { Place of } \\
\text { Residence }\end{array}$ & $\begin{array}{c}\text { Material } \\
\text { Situation } \\
\text { (Self-Assessed) }\end{array}$ & $\begin{array}{c}\text { Material } \\
\text { Situation } \\
\text { (Objectively) }\end{array}$ \\
\hline \multicolumn{8}{|c|}{ Child's Health and Therapy-Module II } \\
\hline $\begin{array}{c}\text { Frequency of control } \\
\text { visits }\end{array}$ & - & - & - & $\begin{array}{c}0.343 \\
(<0.001)\end{array}$ & - & - & $\begin{array}{c}0.251 \\
(0.027)\end{array}$ \\
\hline Age at diagnosis & $\begin{array}{c}0.687 \\
(<0.001)\end{array}$ & $\begin{array}{c}0.354 \\
(<0.001)\end{array}$ & - & $\begin{array}{c}0.354 \\
(<0.001)\end{array}$ & - & - & - \\
\hline Insulin delivery method & - & - & - & - & $\begin{array}{c}0.564 \\
(<0.001)\end{array}$ & $\begin{array}{c}0.588 \\
(<0.001)\end{array}$ & $\begin{array}{c}0.771 \\
(<0.001)\end{array}$ \\
\hline $\begin{array}{l}\text { Regularity of control } \\
\text { visits }\end{array}$ & - & - & $\begin{array}{c}0.157 \\
(0.038)\end{array}$ & - & - & - & - \\
\hline $\begin{array}{l}\text { Attending } \\
\text { physician }\end{array}$ & - & - & - & - & - & - & - \\
\hline $\begin{array}{c}\text { Consultation (last } 12 \\
\text { months) }\end{array}$ & - & - & - & - & $\begin{array}{c}0.507 \\
(<0.001)\end{array}$ & $\begin{array}{c}0.561 \\
(<0.001)\end{array}$ & $\begin{array}{c}0.653 \\
(<0.001)\end{array}$ \\
\hline $\begin{array}{c}\text { Consultation (last } 5 \\
\text { years) }\end{array}$ & - & - & - & $\begin{array}{c}0.274 \\
(0.004)\end{array}$ & $\begin{array}{c}0.529 \\
(<0.001)\end{array}$ & $\begin{array}{c}0.586 \\
(<0.001)\end{array}$ & $\begin{array}{c}0.643 \\
(<0.001)\end{array}$ \\
\hline $\begin{array}{l}\text { Occurrence of } \\
\text { complications }\end{array}$ & - & - & - & - & - & - & - \\
\hline
\end{tabular}




\subsubsection{Influence of Demographic Factors}

The analysis of the collected data indicates a correlation between the occurrence of specific demographic factors and the values of the variables characterizing the impact of the disease on the life of the child and their family, and the possibility of taking care of the child outside the family. The subjective assessment of the family's financial situation was related to the level of expenses incurred from the child's therapy and the occurrence of anxieties related to the child's disease, which was also negatively correlated with the limitation of the child's activity caused by T1D. Similar correlations were observed in the case of the variable describing the average income per person in the family (an objective measure of the family's economic situation), which was also associated with the frequency of follow-up visits to the attending physician. Similar relationships occurred with regard to the child's place of residence, which also affected the frequency of attendance at care or educational institutions.

The strength of the relationship between demographic factors and other variables varied. Cramer's V-value ranged from 0.157 in the case of the association of the child's family type with the regularity of control visits to 0.808 in the case of the child's age and the possibility of entrusting daytime care to a third party (other than the permanent caregiver).

Detailed information on the number and strength of the observed connections is presented in Table 3.

Table 3. Influence of demographic factors.

\begin{tabular}{|c|c|c|c|c|c|c|c|}
\hline $\begin{array}{l}\text { Cramer's V } \\
(p \text {-Value }) 1\end{array}$ & $\begin{array}{l}\text { Child's } \\
\text { Age }\end{array}$ & $\begin{array}{l}\text { Caregiver's } \\
\text { Age }\end{array}$ & $\begin{array}{l}\text { Family } \\
\text { Type }\end{array}$ & $\begin{array}{l}\text { Main } \\
\text { Caregiver }\end{array}$ & $\begin{array}{c}\text { Place of } \\
\text { Residence }\end{array}$ & $\begin{array}{c}\text { Material } \\
\text { Situation } \\
\text { (Self-Assessed) }\end{array}$ & $\begin{array}{c}\text { Material } \\
\text { Situation } \\
\text { (Objectively) }\end{array}$ \\
\hline \multicolumn{8}{|c|}{ Child's and Family's Life-Module III } \\
\hline $\begin{array}{c}\text { Changes in professional } \\
\text { activity }\end{array}$ & - & - & - & - & - & - & - \\
\hline $\begin{array}{c}\text { Limited access to } \\
\text { activities }\end{array}$ & - & - & - & - & $\begin{array}{c}0.224 \\
(0.003)\end{array}$ & $\begin{array}{c}0.242 \\
(<0.001)\end{array}$ & $\begin{array}{c}0.304 \\
(<0.001)\end{array}$ \\
\hline $\begin{array}{c}\text { Change of family } \\
\text { situation }\end{array}$ & - & - & - & $\begin{array}{c}0.321 \\
(0.018)\end{array}$ & - & - & - \\
\hline $\begin{array}{l}\text { Out of pocket health } \\
\text { spending }\end{array}$ & - & - & $\begin{array}{c}0.185 \\
(0.029)\end{array}$ & - & $\begin{array}{c}0.682 \\
(<0.001)\end{array}$ & $\begin{array}{c}0.737 \\
(<0.001)\end{array}$ & $\begin{array}{c}0.493 \\
(<0.001)\end{array}$ \\
\hline Caregiver's concerns & $\begin{array}{c}0.321 \\
(0.007)\end{array}$ & $\begin{array}{c}0.240 \\
(0.040)\end{array}$ & $\begin{array}{c}0.219 \\
(0.006)\end{array}$ & - & $\begin{array}{c}0.239 \\
(0.042)\end{array}$ & $\begin{array}{c}0.254 \\
(0.011)\end{array}$ & $\begin{array}{c}0.252 \\
(0.001)\end{array}$ \\
\hline Child's concerns & $\begin{array}{c}0.414 \\
(<0.001)\end{array}$ & $\begin{array}{c}0.366 \\
(<0.001)\end{array}$ & $\begin{array}{c}0.184 \\
(0.030)\end{array}$ & - & - & - & - \\
\hline $\begin{array}{l}\text { Support } \\
\text { Sources }\end{array}$ & $\begin{array}{c}0.332 \\
(0.006)\end{array}$ & - & - & $\begin{array}{c}0.321 \\
(0.018)\end{array}$ & - & - & - \\
\hline \multicolumn{8}{|c|}{ Provision of Care-Module IV } \\
\hline $\begin{array}{l}\text { Day-time care (3rd } \\
\text { person) }\end{array}$ & $\begin{array}{c}0.808 \\
(<0.001)\end{array}$ & $\begin{array}{c}0.391 \\
(<0.001)\end{array}$ & - & - & - & - & - \\
\hline Night-time care & - & - & - & - & - & - & - \\
\hline $\begin{array}{c}\text { Access to institutional } \\
\text { care }\end{array}$ & $\begin{array}{c}0.762 \\
(<0.001)\end{array}$ & $\begin{array}{c}0.433 \\
(<0.001)\end{array}$ & - & - & $\begin{array}{c}0.314 \\
(0.037)\end{array}$ & - & - \\
\hline
\end{tabular}

Correlations marked with (-) were statistically insignificant $(p>0.05)$.

\subsection{Influence of Health Status}

Significantly fewer connections were observed between the current health condition and the family situation of the child. The amount of health care expenses (out of pocket payments) was related to the type of insulin therapy applied (with the V-value of the Cramer's coefficient being 0.558 ) and the frequency of follow-up visits to attending physicians of other specialties in the last 12 months and 5 years (with the V-value of the Cramer's co-ordinates as 0.588 and 0.592 , respectively). The child's age was important in the case of the possibility of entrusting childcare to persons other than parents (caregivers). The 
lack of such a possibility concerned mainly the youngest children-those under the age of compulsory schooling ( 6 years). The average age of children whose parents could not count on this form of support from other people or institutions $(n=24)$ was 2.79 years.

Detailed information on the number and strength of the observed connections is presented in Table 4.

Table 4. Influence of health status.

\begin{tabular}{|c|c|c|c|c|c|c|c|c|}
\hline $\begin{array}{l}\text { Cramer's V } \\
(p \text {-Value) } 1\end{array}$ & $\begin{array}{l}\text { Age at } \\
\text { Diagno- } \\
\text { sis }\end{array}$ & $\begin{array}{l}\text { Insulin } \\
\text { Delivery } \\
\text { Method }\end{array}$ & $\begin{array}{l}\text { Main } \\
\text { Doctor }\end{array}$ & $\begin{array}{l}\text { Frequency of } \\
\text { Control } \\
\text { Visits }\end{array}$ & $\begin{array}{l}\text { Regularity } \\
\text { of Control } \\
\text { Visits }\end{array}$ & $\begin{array}{l}\text { Consultations } \\
\text { (Last } 12 \text { Months) }\end{array}$ & $\begin{array}{l}\text { Consultations } \\
\text { (Last } 5 \text { Years) }\end{array}$ & $\begin{array}{l}\text { Occurrence } \\
\text { of Complica- } \\
\text { tions }\end{array}$ \\
\hline \multicolumn{9}{|c|}{ Child's and Family's Life-Module III } \\
\hline $\begin{array}{l}\text { Changes in } \\
\text { professional } \\
\text { activity }\end{array}$ & - & $\begin{array}{c}0.141 \\
(0.043)\end{array}$ & - & $\begin{array}{c}0.255 \\
(0.004)\end{array}$ & - & - & - & - \\
\hline $\begin{array}{l}\text { Limited access } \\
\text { to activities }\end{array}$ & - & - & - & - & - & $\begin{array}{c}0.230 \\
(0.001)\end{array}$ & $\begin{array}{c}0.217 \\
(0.003)\end{array}$ & - \\
\hline $\begin{array}{l}\text { Change of } \\
\text { family } \\
\text { Situation }\end{array}$ & - & - & - & - & - & - & - & $0.430(0.001)$ \\
\hline $\begin{array}{l}\text { Out of pocket } \\
\text { health } \\
\text { spending }\end{array}$ & - & $\begin{array}{c}0.558 \\
(<0.001)\end{array}$ & - & $\begin{array}{c}0.244 \\
(0.044)\end{array}$ & $\begin{array}{c}0.261 \\
(0.032)\end{array}$ & $\begin{array}{c}0.588 \\
(<0.001)\end{array}$ & $\begin{array}{c}0.592 \\
(<0.001)\end{array}$ & - \\
\hline $\begin{array}{l}\text { Caregiver's } \\
\text { concerns }\end{array}$ & $\begin{array}{c}0.235 \\
(0.003)\end{array}$ & - & - & - & - & $\begin{array}{l}0.140 \\
0.044)\end{array}$ & - & - \\
\hline $\begin{array}{l}\text { Child's } \\
\text { concerns }\end{array}$ & $\begin{array}{c}0.408 \\
(<0.001)\end{array}$ & - & - & - & - & - & - & - \\
\hline $\begin{array}{l}\text { Support } \\
\text { sources }\end{array}$ & & & $\begin{array}{c}0.349 \\
(<0.001)\end{array}$ & $\begin{array}{c}0.258 \\
(0.039)\end{array}$ & - & - & - & - \\
\hline \multicolumn{9}{|c|}{ Provision of Care-Module IV } \\
\hline $\begin{array}{l}\text { Day-time care } \\
\text { (3rd person) }\end{array}$ & $\begin{array}{c}0.592 \\
(<0.001)\end{array}$ & - & - & - & - & - & - & - \\
\hline Night-time care & $\begin{array}{c}0.241 \\
(0.046)\end{array}$ & - & $\begin{array}{c}0.259 \\
(0.001)\end{array}$ & - & - & - & - & - \\
\hline $\begin{array}{l}\text { Access to } \\
\text { institutional } \\
\text { care }\end{array}$ & $\begin{array}{c}0.628 \\
(<0.001)\end{array}$ & - & - & - & - & - & - & - \\
\hline
\end{tabular}

Correlations marked with (-) were statistically insignificant $(p>0.05)$.

\section{Discussion}

The aim of the study was to determine the degree of prevalence of selected problems in the functionality of the family of a child with T1D. The study covered the difficulties in accessing health and care services for children and young people with T1D in Poland. The relationship of these problems with socioeconomic status (SES) and the health condition of the respondents was also assessed.

The number of caregivers of children and adolescents with T1D who took part in the study (206 people) was significant, as it amounted to almost $1 \%$ of the total number of people under 18 years of age suffering from T1D in Poland (about 22,000). For this reason, the obtained results may reflect the situation of this social group as faithfully as possible.

The studies conducted so far show that low SES is associated with a number of risk factors among T1D patients, such as: poor glycemic control [30-32], smoking [33,34], hypertension [34,35], and an increased number of hospitalizations [36]. They also contribute to an increased risk of death [37-40] in the T1D population.

A diagnosis of T1D at a young age, and therefore a long disease period, may intensify the effect of these factors. Among children and adolescents with T1D, it was observed that low SES was accompanied by worse glycemic control results and compliance with therapeutic adherence [41,42]. The results of the conducted research confirm these observations. The groups of respondents with higher and lower income (both subjectively assessed and in absolute terms) clearly differed in the use of modern forms of therapy (Personal insulin pumps), as well as medical check-up visits, aimed at early diagnosis of possible T1D complications (ophthalmological, nephrological and neurological consultations). The spatial 
distribution of poverty in Poland may partially explain this relationship. This problem occurs most strongly in small and medium-sized towns, and to a lesser extent in villages, large cities and the largest cities [43]. The results of the study indicate that the place of residence was associated with a similar number of variables describing the patient's health, family situation, and access to care and educational services (seven associations), as was income level (six associations). However, these relationships were often of a weaker nature (with a lower Cramer's V coefficient).

The importance of the income level, when assessed objectively in particular, is shown by its connection with the applied form of insulin therapy and the use of specialist consultations. This may be due to the fact that PIP therapy, similarly to the use of CGM, is only partially reimbursed under general health insurance. The use of PIP and CGM therefore imposes higher caregiver fees. This assumption is confirmed by the observed strong correlation of these phenomena with the declared level of private expenditure on health care (out of pocket payments). Similar results were obtained in studies carried out in Germany and Canada concerning, respectively, the choice of treatment with insulin pumps [42] and the willingness to pay for better T1D therapy [44,45].

The vast majority of therapeutic recommendations assume that a patient with T1D should consult with a doctor at least every $3-4$ months [46]. A similar recommendation is formulated by the Polish Diabetes Society [47]. It is also advisable for the patient to undergo specialist consultations (ophthalmological, nephrological, and neurological). Adherence to these recommendations is essential for the success of the treatment (primarily expressed in better glycemic control). Following these recommendations also has the potential to reduce the SES-induced gap $[48,49]$. Therefore, the low average number of visits to the attending physician (2.7 visits per year) and specialist consultations (less than 0.2 in the last 12 months and about 0.25 in the last 5 years) is of concern. Taking into account the recommended frequency of such consultations (ophthalmological consultations in particular), as well as the average age of patients (7.9 years) and time from the diagnosis of the disease (approximately 3 years) in the study population, we should expect these values to be several times higher. A partial explanation of the observed situation may be the general problems with the availability of certain benefits in the public health care system in Poland [50,51]. In this context, the low percentage of children and adolescents, as well as their caregivers, who express concerns about their health and the possibility of complications, is surprising. This may be due to insufficient knowledge of underage patients and their caregivers about the disease itself and of the importance of complying with therapeutic recommendations [52,53].

The study did not confirm the existence of a relationship between the place of residence and the availability of care services (e.g., a nursery) and education services (kindergarten) for children under compulsory school age (up to 6 years of age). On the other hand, the results of this study indicate that the connection of the parents' possibility of entrusting another person (guardian) or institution (nursery, kindergarten) with caring for a child suffering from T1D is related to the child's age. This situation may be caused by the lack of preparation of people and institutions to meet the requirements of caring for a child with T1D [54], as well as by the lack of appropriate legal regulations that would require the admission of such a child or ensure that their special needs are taken into account during their stay in the facility.

The strongest correlations between observed variables are presented in Figure 2. 


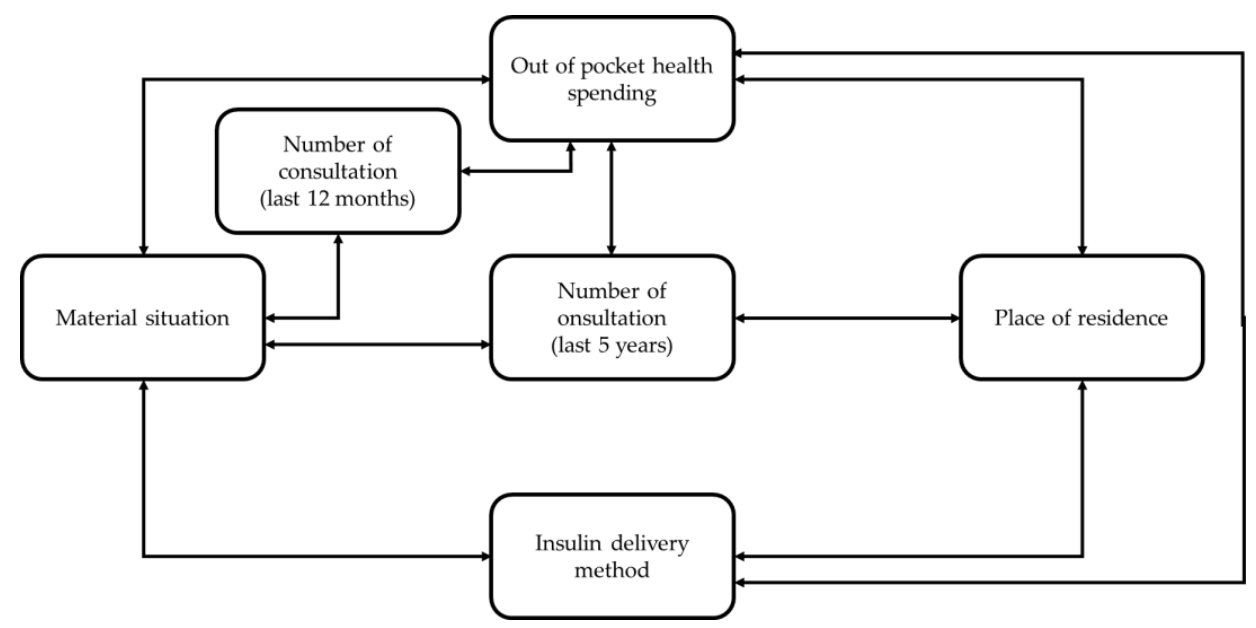

Figure 2. Strongest correlations.

\section{Study Limitations}

This study was a preliminary research (exploratory study). It was conducted on a smaller-than-optimal sample of respondents, whose selection (membership in one of two Facebook self-help groups) was not random. The size of the sample made it impossible to conduct a more in-depth statistical analysis, in particular one that could illustrate potential further differentiation of the situation of individual groups of children and adolescents with T1D in Poland.

\section{Conclusions}

Subject to the limitations outlined in the previous section, the conducted research shows the existence of strong links between income level, the availability of modern therapy methods (insulin pumps, CGM systems), and the possibility of using specialist consultations for children and adolescents with T1D in Poland. The nature of the study does not allow a determination as to whether this relationship is direct or whether income level interacts with other factors, such as the level of education or place of residence.

The discrepancy of the declared model of diabetes care with the current scientific knowledge and recommendations of medical societies raises concerns.

Unequal access to modern forms of therapy and the suboptimal nature of the actually implemented care regimen may have negative effects on the health of the population of children and adolescents with T1D. Therefore, the factors influencing this state of affairs should be the subject of further research

It is advisable to carry out a further, in-depth analysis of the situation of children with T1D in Poland. The results of such a study (optimally with a much larger random sample) could be an important contribution to the formation of public policies in the field of health care and social policy, as well as an aid in everyday clinical practice.

Author Contributions: Conceptualization, J.G.-S.; methodology J.G.-S. and K.S.; software, K.S.; validation, J.G.-S. and K.S.; formal analysis, J.G.-S.; investigation, J.G.-S., M.Z. and K.S.; resources, J.G.S.; data curation, J.G.-S. and M.Z.; writing-original draft preparation, J.G.-S., M.Z. and K.S.; writingreview and editing, J.G.-S. and K.S.; visualization, K.S.; supervision, J.G.-S.; project administration, J.G.-S.; funding acquisition, J.G.-S. All authors have read and agreed to the published version of the manuscript.

Funding: This research was funded by Centre of Postgraduate Medical Education, Warsaw, Poland (Centrum Medyczne Kształcenia Podyplomowego).

Institutional Review Board Statement: The study was conducted according to the guidelines of the Declaration of Helsinki, and approved by the Institutional Review Board of the Centre of Postgraduate Medical Education (no. 501-4-44-28-18). 
Informed Consent Statement: Informed consent was obtained from all subjects involved in the study.

Data Availability Statement: The data presented in this study are available on request from the corresponding author. The data are not publicly available due to technical reasons.

Acknowledgments: The authors wish to acknowledge the support given by administrators of Facebook groups providing assistance to T1D adolescents and their families in the effort to gather data for this study.

Conflicts of Interest: The authors declare that there is no conflict of interest.

\section{References}

1. Knip, M.; Siljander, H. Autoimmune mechanisms in type 1 diabetes. Autoimmun. Rev. 2008, 7, 550-557. [CrossRef] [PubMed]

2. Banday, M.Z.; Sameer, A.S.; Nissar, S. Pathophysiology of diabetes: An overview. Avicenna J. Med. 2020, 10, 174-188. [CrossRef] [PubMed]

3. Pociot, F.; Lernmark, Å. Genetic risk factors for type 1 diabetes. Lancet 2016, 387, 2331-2339. [CrossRef]

4. Redondo, M.J.; Jeffrey, J.; Fain, P.R.; Eisenbarth, G.S.; Orban, T. Concordance for islet autoimmunity among monozygotic twins. N. Engl. J. Med. 2008, 359, 2849-2850. [CrossRef]

5. Rewers, M.; Ludvigsson, J. Environmental risk factors for type 1 diabetes. Lancet 2016, 387, 2340-2348. [CrossRef]

6. Streisand, R.; Monaghan, M. Young children with type 1 diabetes: Challenges, research, and future directions. Curr. Diab. Rep. 2014, 14, 520. [CrossRef]

7. Patterson, C.C.; Dahlquist, G.G.; Gyurus, E.; Green, A.; Soltesz, G. Incidence trends for childhood Type 1 diabetes in Europe during 1989-2003 and predicted new cases 2005-2020: A multicentre prospective registration study. Lancet 2009, 373, 2027-2033. [CrossRef]

8. Negrato, C.A.; Dias, J.P.; Teixeira, M.F.; Dias, A.; Salgado, M.H.; Lauris, J.R.; Montenegro, R.M., Jr.; Gomes, M.B.; Jovanovic, L. Temporal trends in incidence of Type 1 diabetes between 1986 and 2006 in Brazil. J. Endocrinol. Investig. 2010, 33, 373-377. [CrossRef]

9. Secrest, A.M.; Becker, D.J.; Kelsey, S.F.; Ronald, L.E.; Trevor, O.J. Cause-specific mortality trends in a large population-based cohort with long-standing childhood-onset type 1 diabetes. Diabetes 2010, 59, 3216-3222. [CrossRef] [PubMed]

10. Andrade, C.J.; Alves, C. Influence of socioeconomic and psychological factors in glycemic control in young children with type 1 diabetes mellitus. J. Pediatr. 2019, 95, 48-53. [CrossRef] [PubMed]

11. Healthy Data Portal (Portal Zdrowe Dane). Available online: https://zdrowedane.nfz.gov.pl/pluginfile.php/205/mod_resource/ content/4/nfz_o_zdrowiu_cukrzyca.pdf (accessed on 30 December 2020).

12. Myśliwiec, M. Cukrzyca u dzieci-etiopatogeneza, diagnostyka i terapia. Forum Med. Rodz. 2007, 1, 125-133.

13. Brzeziński, M. Is High Inequality an Issue i Poland? IBS Policy Paper 2017. Available online: https://ibs.org.pl/app/uploads/20 17/06/IBS_Policy_Paper_01_2017_en.pdf (accessed on 30 December 2020).

14. Sochocka, L.; Ledwoń, E.; Rak, S.; Szwamel, K. Self-assessment of teachers' knowledge regarding their preparation for caring for a child with type 1 diabetes at school. Piel. Zdr. Publ. 2019, 9, 183-190. Available online: http://www.pzp.umed.wroc.pl/pdf/20 19/9/3/183.pdf (accessed on 30 December 2020). [CrossRef]

15. Sandeep, G.; Bhadada, S.; Kate, N.; Sarkar, S.; Bhansali, A.; Avasthi, A.; Sharma, S.; Goel, R. Coping and caregiving experience of parents of children and adolescents with type-1 diabetes: An exploratory study. Perspect. Clin. Res. 2016, 7, 32-39. [CrossRef]

16. Starfield, B.; Bergner, M.; Ensminger, M.; Ri-ley, A.; Ryan, S.; Green, B.; McGauhey, P.; Skinner, A.; Kim, S. Adolescent health status measurement: Development of the Child Health and Illness Profile. Pediatrics 1993, 91, 430-435.

17. Landgraf, J.E.; Ware, J.E., Jr. The Child Health Questionnaire (CHQ): A User's Manual; The Health Institute: Boston, MA, USA, 1996.

18. Verrips, E.G.H.; Vogels, T.G.C.; Koopman, H.M.; Theunissen, N.C.M.; Kamphius, R.P.; Fekkes, M. Measuring health-related quality of life in a child population. Eur. J. Public Health 1999, 9, 114-119. [CrossRef]

19. Seid, M.; Varni, J.W.; Kurtin, P.S. Measuring quality of care for vulnerable children: Challenges and conceptualization of a pediatric outcome measure of quality. Am. J. Med. Qual. 2000, 15, 182-188. [CrossRef] [PubMed]

20. Ingersoll, G.M.; Marrero, D.G. A modified quality-of-life measure for youths: Psychometric properties. Diabetes Educ. 1991, 17, 114-118. [CrossRef] [PubMed]

21. Madsen, S.D.; Roisman, G.I.; Collins, W.A. The intersection of adolescent development and intensive intervention: Age-related psychosocial correlates of treatment regimens in the Diabetes Control and Complications Trial. J. Pediatr. Psychol. 2002, 27, 451-459. [CrossRef] [PubMed]

22. Varni, J.W.; Burwinkle, T.M.; Jacobs, J.R.; Gottschalk, M.; Kaufman, F.; Jones, K.I. The PedsQL in Type 1 and Type 2 Diabetes: Reliability and validity of the Pediatric Quality of Life Inventory Generic Core Scales and Type 1 Diabetes Module. Diabetes Care 2003, 26, 631-637. [CrossRef] [PubMed]

23. Varni, J.W.; Seid, M.; Rode, C.A. The PedsQL: Measurement model for the pediatric quality of life inventory. Med. Care 1999, 37, 126-139. [CrossRef] [PubMed]

24. Varni, J.W.; Seid, M.; Kurtin, P.S. PedsQL 4.0: Reliability and validity of the Pediatric Quality of Life Inventory version 4.0 generic core scales in healthy and patient populations. Med. Care 2001, 39, 800-812. [CrossRef] [PubMed] 
25. Barczykowska, E.; Juszczak, A.; Ślusarz, R.; Grabinska, M.; Kurylak, A. Quality of life in children aged 8-12 with diabetes treated with an insulin pump. Med. Sci. Technol. 2011, 52, 57-61.

26. Caferoğlu, Z.; İnanç, N.; Hatipoğlu, N.; Kurtoğlu, S. Health-Related Quality of Life and Metabolic Control in Children and Adolescents with Type 1 Diabetes Mellitus. J. Clin. Res. Pediatr. Endocrinol. 2016, 8, 67-73. [CrossRef] [PubMed]

27. Lin, K.; Yang, X.; Yin, G.; Lin, S. Diabetes Self-Care Activities and Health-Related Quality-of-Life of individuals with Type 1 Diabetes Mellitus in Shantou, China. J. Int. Med. Res. 2016, 44, 147-156. [CrossRef] [PubMed]

28. Zrebiec, J.F.; Jacobson, A.M. What attracts patients with diabetes to an internet support group? A 21-month longitudinal website study. Diabetes Med. 2001, 18, 154-158. [CrossRef]

29. Wu, N.; Brazeau, A.S.; Nakhla, M.; Chan, D.; Da Costa, D.; Mukerji, G.; Butalia, S.; Pacaud, D.; Henderson, M.; Panagiotopoulos, C.; et al. Type 1 Diabetes Mellitus Virtual Patient Network as a Peer Support Community: Protocol for Social Network Analysis and Content Analysis. JMIR Res. Protoc. 2020, 9, 18714. [CrossRef]

30. Ismail, I.S.; Nazaimoon, W.M.; Mohamad, W.B.; Letchuman, R.; Singaraveloo, M.; Pendek, R. Sociodemographic determinants of glycaemic control in young diabetic patients in peninsular Malaysia. Diabetes Res. Clin. Pract. 2000, 47, 57-69. [CrossRef]

31. Araujo, M.B.; Mazza, C.S. Assessment of risk factors of poor metabolic control in type 1 diabetic children assisted in a public hospital in Argentina. Pediatr. Diabetes 2008, 9, 480-487. [CrossRef] [PubMed]

32. Hassan, K.; Loar, R.; Anderson, B.J.; Heptulla, R.A. The role of socioeconomic status, depression, quality of life, and glycemic control in type 1 diabetes mellitus. J. Pediatr. 2006, 149, 526-531. [CrossRef]

33. Unwin, N.; Binns, D.; Elliott, K.; Kelly, W.F. The relationships between cardiovascular risk factors and socio-economic status in people with diabetes. Diabetes Med. 1996, 13, 72-79. [CrossRef]

34. Nadas, J.; Putz, Z.; Fovenyi, J.; Gaal, Z.; Gyimesi, A.; Hidvegi, T. Cardiometabolic risk and educational level in adult patients with type 1 diabetes. Acta Diabetol. 2009, 46, 159-162. [CrossRef]

35. Chaturvedi, N.; Jarrett, J.; Shipley, M.J.; Fuller, J.H. Socioeconomic gradient in morbidity and mortality in people with diabetes: Cohort study findings from the Whitehall Study and the WHO Multinational Study of Vascular Disease in Diabetes. BMJ 1998, 316, 100-105. [CrossRef] [PubMed]

36. Kovacs, M.; Charron-Prochownik, D.; Obrosky, D.S. A longitudinal study of biomedical and psychosocial predictors of multiple hospitalizations among young people with insulin-dependent diabetes mellitus. Diabetes Med. 1995, 12, 142-148. [CrossRef]

37. Secrest, A.M.; Costacou, T.; Gutelius, B.; Miller, R.G.; Songer, T.J.; Orchard, T.J. Association of Socioeconomic Status with Mortality in Type 1 Diabetes: The Pittsburgh Epidemiology of Diabetes Complications (EDC) Study. Ann. Epidemiol. 2011, 21, 367-373. [CrossRef]

38. Matsushima, M.; Shimizu, K.; Maruyama, M.; Nishimura, R.; LaPorte, R.E.; Tajima, N. Socioeconomic and behavioural risk factors for mortality of individuals with IDDM in Japan: Population-based case-control study. Diabetes Epidemiology Research International (DERI) US-Japan Mortality Study Group. Diabetologia 1996, 39, 710-716. [CrossRef]

39. Roper, N.A.; Bilous, R.W.; Kelly, W.F.; Unwin, N.C.; Connolly, V.M. Excess mortality in a population with diabetes and the impact of material deprivation: Longitudinal, population based study. BMJ 2001, 322, 1389-1393. [CrossRef] [PubMed]

40. Forssas, E.; Arffman, M.; Koskinen, S.; Reunanen, A.; Keskimaki, I. Socioeconomic differences in mortality among diabetic people in Finland. Scand. J. Public Health 2010, 38, 691-698. [CrossRef]

41. Caccavale, L.J.; Weaver, P.; Chen, R.; Streisand, R.; Holmes, C.S. Family Density and SES Related to Diabetes Management and Glycemic Control in Adolescents With Type 1 Diabetes. J. Pediatr. Psychol. 2015, 40, 500-508. [CrossRef]

42. Mönkemöller, K.; Müller-Godeffroy, E.; Lilienthal, E.; Heidtmann, B.; Becker, M.; Feldhahn, L.; Freff, M.; Hilgard, D.; Krone, B.; Papsch, M.; et al. The association between socio-economic status and diabetes care and outcome in children with diabetes type 1 in Germany: The DIAS study (diabetes and social disparities). Pediatr. Diabetes 2019, 20, 637-644. [CrossRef] [PubMed]

43. Economic Poverty in Poland in 2019 (Zasięg Ubóstwa Ekonomicznego w Polsce w 2019 Roku). Available online: https: //stat.gov.pl/download/gfx/portalinformacyjny/pl/defaultaktualnosci/5487/14/7/1/zasieg_ubostwa_ekonomicznego_w_ polsce_w_2019_r.pdf (accessed on 30 December 2020).

44. Guimarães, C.; Marra, C.A.; Colley, L.; Gill, S.; Simpson, S.H.; Meneilly, G.S.; Queiroz, R.H.; Lynd, L.D. A valuation of patients' willingness-to-pay for insulin delivery in diabetes. Int. J. Technol. Assess. Health Care 2009, 25, 359-366. [CrossRef]

45. Guimarães, C.; Marra, C.A.; Colley, L.; Gill, S.; Simpson, S.; Meneilly, G.; Queiroz, R.H.; Lynd, L.D. Socioeconomic differences in preferences and willingness-to-pay for insulin delivery systems in type 1 and type 2 diabetes. Diabetes Technol. Ther. 2009, 11, 567-573. [CrossRef] [PubMed]

46. Children and Adolescents. Standards of Medical Care in Diabetes-2021, American Diabetes Association. Diabetes Care 2021, 44, S180-S199. [CrossRef] [PubMed]

47. Araszkiewicz, A.; Bandurska-Stankiewicz, E.; Budzyński, A.; Cypryk, K.; Czech, A.; Czupryniak, L.; Drzewoski, J.; Dzida, G.; Dziedzic, T.; Franek, E.; et al. Zalecenia Kliniczne Dotyczące Postępowania u Chorych na Cukrzycę 2020—Stanowisko PTD. Diabetol. Prakt. 2020, 6, 1-106.

48. Gandhi, K.; Vu, B.K.; Eshtehardi, S.S.; Wasserman, R.M.; Hilliard, M.E. Adherence in adolescents with Type 1 diabetes: Strategies and considerations for assessment in research and practice. Diabetes Manag. 2015, 5, 485-498. [CrossRef]

49. Patton, S.R. Adherence to glycemic monitoring in diabetes. J. Diabetes Sci. Technol. 2015, 9, 668-675. [CrossRef] 
50. OECD/European Observatory on Health Systems and Policies (2017), Poland: Country Health Profile 2017, State of Health in the EU, OECD Publishing, Paris/European Observatory on Health Systems and Policies, Brussels. Available online: http: / /dx.doi.org/10.1787/9789264283510-en (accessed on 30 December 2020).

51. Sowa-Kofta, A. Addressing the Challenges of the Healthcare System in Poland, ESPN Flash Report 2018/14. Available online: https: / / ec.europa.eu/social/BlobServlet?docId=19206\&langId=en (accessed on 30 December 2020).

52. Zegarlicka-Poręba, M.; Jarosz-Chobot, P. Problem Cukrzycy i Radzenia Sobie z Choroba-Ujęcie Psychologiczne, Diabetologii na co Dzień. 2013. Available online: http:/ / diabetologiaonline.pl/pielegniarka_poradnik,info,159.html (accessed on 30 December 2020).

53. Borus, J.S.; Laffel, L. Adherence challenges in the management of type 1 diabetes in adolescents: Prevention and intervention. Curr. Opin. Pediatr. 2010, 22, 405-411. [CrossRef] [PubMed]

54. Siminerio, L.M.; Albanese-O’Neill, A.; Chiang, J.L.; Hathaway, K.; Jackson, C.C.; Weissberg-Benchell, J.; Wright, J.L.; Yatvin, A.L.; Deeb, L.C. Care of Young Children with Diabetes in the Child Care Setting: A Position Statement of the American Diabetes Association. Diabetes Care 2014, 37, 2834-2842. [CrossRef] 